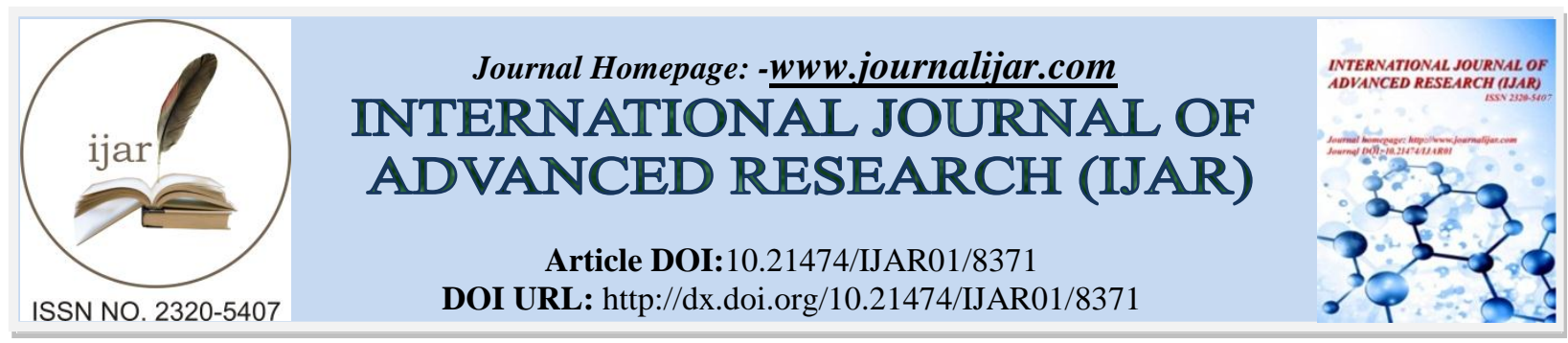

RESEARCH ARTICLE

\title{
SEROPREVALENCE OF TOXOPLASMA GONDII ANTIBODIES IN ABORTED WOMEN USING ENZYME LINKED IMMUNESORBENT ASSAY(ELISA) IN THI-QAR PROVINCE, IRAQ.
}

\author{
Abeer T. Ali ${ }^{1}$, Dawood S. Mahdi ${ }^{1}$ and A.H. Awad ${ }^{2}$. \\ 1. Dept. of Medical Lab.Tech./ College of Health \& Medical Technology/ Southern Technical University/ \\ Republic of Iraq. \\ 2. Dept. Biology/ College of education Pure Science/ University of Basrah/ Iraq.
}

\section{Manuscript Info}

\section{Manuscript History}

Received: 10 November 2018

Final Accepted: 12 December 2018

Published: January 2019

Key words:-

T. gondii, Prevalence, ELISA, Aborted women, Thi-Qar, Iraq.

\begin{abstract}
Toxoplasmosis is the disease that caused by Toxoplasma gondii which can infected all worm blood animals and it is most famous parasite in human.

The study aims is to show the seroprevalenace of toxoplasmosis among abortive women in Thi-Qar province. Its include 470 blood samples collected from abortive women in emergency unit of Bent -Al Huda and Al-Hubboby Hospitals and 30 women as a control(women with normal pregnancy and birth without infected with toxoplasmosis). Samples were collected from October 2017 till October 2018 with age $(15-40)$ years.

These samples were first tested with latex agglutination test (LAT) to detect the positive sample, which give agglutinate, then with Enzyme Linked Immunesorbent Assay (ELISA) to detect IgG,IgM antibodies of Toxoplasma.It was found from the present study that the (ELISA) test is more specific for Toxoplasma diagnosis than (LAT).The seroprevalence for $\operatorname{IgG}$ antibody was $36.45 \%$, IgM $4.52 \%$ and for both $1.94 \%$. the high seroprvalent of toxoplasmosis was found in urban (26.5\%) than rural (16.5\%).In age group (20-24) years the seroprevalent was $12.58 \%$ found and the high ratio(47.14\%) was recorded in the aborted women with first trimester more than second trimester $(30.65 \%)$.

The purpose of the present study is to evaluate the seroprevalence of $T$. gondii antibodies (IgG, $\operatorname{IgM})$ in aborted women and the association between this parasite and Cytomegalovirus and Rubella.Risk factors (age, sex, time and number of abortion) on infection also investigated.
\end{abstract}

Copy Right, IJAR, 2017,. All rights reserved.

\section{Introduction:-}

Toxoplasma gondii is an obligate intracellular parasite that widely prevalent in human and another animals in all countries $[1,2]$. It is causes toxoplasmosis disease, which infected all warm blood animals [3]. The rout of transmission of Toxoplasma to human is through ingestion the sporulated oocyst or tissue cyst of infected animal [4]. The congenital toxoplasmosis is most clinical important, it`s infection to the pregnancy causes death to fetus or sever damage such as hydrocephalus or retinochoroidities $[5,6]$.

Corresponding Author:-Abeer T. Ali.

Address:-Dept. of Medical Lab.Tech./ College of Health \& Medical Technology/ Southern Technical University/ Republic of Iraq. 
The seroprevalent of toxoplasmosis in different countries is depend on the various factors such as, Age, nutritional habitation, contact with cats, animals, and geographical condition [7]. The higher rate of seroprevalent was recorder in France $88 \%$, due to eating of raw meat [8]. In the Arabic countries, the seroprovalent show different rate (58.2, 26, 25, 81.4)\% in Kuwait,[9], Jordan,[10], Saudi Arabia,[11], and in Egypt [12] respectively.

In Baghdad province the prevalence rate $9.4 \%$ of women between (20-61) years old [13]. In Al-Najaf city, the infection rate in women was 40.4\% [14]. In Basrah the seroprevalent was (41.1\%, 52\%) [15].while in Thi-Qar the seroprevalent in the city was $61 \%$ by (LAT) test and by ELISA (18\% IgM, 32\% IgG) [16].

T. gondii infection can be diagnosis with different methods such as serological test, Molecular test, skin test, and histological demonstration parasite [17]. The serological test (ELISA) which is a wildly used for detected the antibody of Toxoplasma, IgG for a chronic infection and IgM for acute infection [18].

\section{Material and Methods:-}

Blood samples(470) of abortive women were collected from emergency unit of Bent-Al Huda Hospital and AlHabboby Hospital, in Thi-Qar province during the period from October 2017 till October 2018. Five ml. of blood samples were collected from each abortive woman. Three ml. of blood placed in gel tube, centrifuged and then the collected serum were used in serological test (Latex and ELISA).

Each serum sample collected was tested with latex agglutination (spinarect company from Spain).The result is consider positive if the agglutination appeared after the serum and latex solution added to each other on the slide.

Samples gave agglutination result (310), were tested with ELISA test Kit (forsight company in Germany) to detect the antibodies of T.gondii according to the manufacturers 'instructions.

All these samples were tested for CMV and Rubella to differential diagnosis by using (forsightkit, Germany) according to the same manufacture procedure of Toxoplasma kit.

\section{Calculation of results for IgG and IgM antibodies:-}

The absorbance value of each sample was divided by the cut-off value, and the results were compared with the following ratios to differentiate between positive and negative sample.

If the result value is more than $>1.1$ it is positive case and if the result value is less than $<0.9$ it is negative case.

\section{Results:-}

\section{Latex test:-}

The current study showed a prevalence infection rate $66 \%$ T.gondii among 470 examined women who suffering from abortion using latex agglutination test.

\section{Seroprevalence of $\mathrm{T}$. gondiiin aborted women using ELISA test:-}

\section{According to the antibodies:-}

The total percentage of seropositive of $T$. gondii antibodies of aborted women was (43\%), while the total percentage of seronegative was $57 \%$. The percentage of $\operatorname{IgG}$ was $36.45 \%$, and $\operatorname{IgM} 4.52 \%$ (Table.1).

Table 1:-Seroprevalence of T.gondii in aborted women using ELISA test.

\begin{tabular}{|l|c|c|c|c|c|c|}
\hline \multicolumn{2}{|l|}{ Antibodies } & IgG & IgM & IgG\&IgM & Total & \multicolumn{2}{|l|}{ Statistics } \\
\hline \multirow{4}{*}{ Seropositive } & No. & $113^{\mathrm{a}}$ & $14^{\mathrm{b}}$ & $6^{\mathrm{c}}$ & 133 & \multicolumn{2}{|c|}{$\mathrm{X}^{2}=160$} \\
\cline { 2 - 7 } & $\%$ & 36.45 & 4.52 & 1.94 & 43 & \\
\hline
\end{tabular}

The difference in small letter means significant. 


\section{According to the age groups:-}

The high total percentage of $T$. gondii seropositive antibodies was $12.58 \%$ at age group (20-24) year and the lowest value $2.58 \%$ at age group $>40$ year, while the high total percentage of seronegative (IgG-, IgM-) was $14.19 \%$ at age group 20-24 year, and the lowest $4.83 \%$ at age group $>40$ year( Table. 2 ).

Table 2:-Seroprevalenace of T.gondii antibodies by ELISA test according to the age groups in 310 abortive women.

\begin{tabular}{|c|c|c|c|c|c|}
\hline \multirow[b]{2}{*}{$\begin{array}{l}\text { Age group } \\
\text { (years) }\end{array}$} & \multicolumn{2}{|c|}{ Positive ELISA } & \multicolumn{2}{|c|}{ Negative ELISA } & \multirow[b]{2}{*}{ Statistics } \\
\hline & No. & $\%$ & No. & $\%$ & \\
\hline $15-19$ & $13^{\mathrm{b}}$ & 4.19 & $24^{\mathrm{a}}$ & 7.74 & \multirow{7}{*}{$\begin{array}{c}X^{2}=61 \\
D F=11 \quad P \leq 0.05\end{array}$} \\
\hline $20-24$ & $39^{\mathrm{b}}$ & 12.58 & $44^{\mathrm{a}}$ & 14.19 & \\
\hline $25-29$ & $32^{\mathrm{a}}$ & 10.32 & $38^{\mathrm{a}}$ & 12.25 & \\
\hline $30-34$ & $27^{b}$ & 8.71 & $36^{\mathrm{a}}$ & 11.61 & \\
\hline $35-39$ & $14^{\mathrm{a}}$ & 4.52 & $20^{\mathrm{a}}$ & 6.5 & \\
\hline$>40$ & $8^{\mathrm{b}}$ & 2.58 & $15^{\mathrm{a}}$ & 4.83 & \\
\hline Total $=310$ & 133 & 43 & 177 & 57 & \\
\hline
\end{tabular}

\section{According to the trimester:-}

Table 3 show the percentage of positive $\operatorname{IgG}+$, IgM+ and both $(\operatorname{IgM}+\& \operatorname{IgG}+)$ of Toxoplasma for $1^{\text {st }}$ trimester $85 \%$, $11.32 \%$, and $3.77 \%$ respectively.

Table 3.Seroprevalence of $T$. gondii antibodies using ELISA test according to the trimester.

\begin{tabular}{|c|c|c|c|c|c|c|c|}
\hline \multirow{2}{*}{$\begin{array}{c}\text { Age group } \\
\text { (years) }\end{array}$} & \multicolumn{2}{|c|}{ IgG } & \multicolumn{2}{|c|}{ IgM } & \multicolumn{2}{c|}{ IgG+ \&IgM+ } & \multirow{2}{*}{ Statistics } \\
\cline { 1 - 7 } $1^{\text {st }} \mathrm{n}=106$ & $90^{\mathrm{a}}$ & 85 & $12^{\mathrm{b}}$ & 11.32 & $4^{\mathrm{c}}$ & 3.77 & $\begin{array}{c}\mathrm{X}^{2}=127 \quad \mathrm{DF}=2 \\
\mathrm{P} \leq 0.05\end{array}$ \\
\hline $\begin{array}{c}2^{\text {nd }} \\
\mathrm{n}=19\end{array}$ & $15^{\mathrm{a}}$ & 78.94 & $2^{\mathrm{b}}$ & 10.53 & $2^{\mathrm{b}}$ & 10.53 & $\begin{array}{c}\mathrm{X}^{2}=6 \quad \mathrm{DF}=2 \mathrm{P} \leq \\
0.05\end{array}$ \\
\hline $\begin{array}{c}3^{\text {rd }} \\
\mathrm{n}=8\end{array}$ & $8^{\mathrm{a}}$ & 100 & $0^{\mathrm{b}}$ & 0 & $0^{\mathrm{b}}$ & 0 & $\begin{array}{c}\mathrm{X}^{2}=1.00 \quad \mathrm{DF}=1 \\
\mathrm{P} \leq 1.00^{\mathrm{NS}}\end{array}$ \\
\hline Total 133 & $113^{\mathrm{a}}$ & 85 & $14^{\mathrm{b}}$ & 10.52 & $6^{\mathrm{c}}$ & 4.51 & $\begin{array}{c}\mathrm{X}^{2}=160 \quad \mathrm{DF}=2 \\
\mathrm{P} \leq 0.05\end{array}$ \\
\hline Statistics & $\begin{array}{c}\mathrm{X}^{2}=110 \mathrm{DF}=2 \\
\mathrm{P} \leq 0.05^{*}\end{array}$ & $\mathrm{X}^{2}=7 \quad \mathrm{DF}=1 \mathrm{P} \leq 0.05^{*}$ & $\begin{array}{c}\mathrm{X}^{2}=0.66 \quad \mathrm{DF}=1 \\
\mathrm{P} \leq 0.44^{\mathrm{NS}}\end{array}$ & \\
\hline
\end{tabular}

\section{According to miscarriage:-}

The high percentage of IgG+ antibodies of aborted women was $100 \%$ at three miscarriage or more and the lowest $78.57 \%$ at single miscarriage. The ratio of IgM+ was recorded at first, and second $(15.71 \%, 8.11 \%)$ respectively, while no IgM was recorded at third miscarriage (Table.4).

Table 4:-Seroprevalence of toxoplasmosis antibodies using ELISA test according to the miscarriage in 133 aborted women.

\begin{tabular}{|c|c|c|c|c|c|c|}
\hline \multirow[t]{2}{*}{ Miscarriage } & \multicolumn{2}{|c|}{ IgM+ } & \multicolumn{2}{|c|}{$\mathrm{IgG}+$} & \multicolumn{2}{|c|}{ IgG+ \&IgM+ } \\
\hline & No & $\%$ & No & $\%$ & No & $\%$ \\
\hline $\begin{array}{c}\text { Single } \\
n=70\end{array}$ & $11^{\mathrm{b}}$ & 15.71 & $55^{\mathrm{a}}$ & 78.57 & $4^{c}$ & 6.2 \\
\hline $\begin{array}{c}\text { Second } \\
\mathrm{n}=37\end{array}$ & $3^{\mathrm{b}}$ & 8.11 & $32^{\mathrm{a}}$ & 86.48 & $2^{\mathrm{b}}$ & 5.41 \\
\hline $\begin{array}{c}\text { More than } 3 \\
n=26\end{array}$ & 0 & 0 & $26^{\mathrm{a}}$ & 100 & 0 & 0 \\
\hline Total $=133$ & $14^{\mathrm{b}}$ & 10.52 & $116^{\mathrm{a}}$ & 90.62 & $6^{c}$ & 4.7 \\
\hline Statistics & \multicolumn{2}{|c|}{$\begin{array}{c}\mathrm{X}^{2}=5 \quad \mathrm{DF}=1 \\
\mathrm{P} \leq 0.05^{*}\end{array}$} & $X^{2}=12$ & $\mathrm{P} \leq$ & \multicolumn{2}{|c|}{$\begin{array}{c}\mathrm{X}^{2}=0.66 \mathrm{DF}=1 \\
\mathrm{P} \leq 0.41^{\mathrm{NS}}\end{array}$} \\
\hline
\end{tabular}




\section{According to residency:-}

Table 5:-Show the high percentage seropositive antibodies of Toxoplasma $26.5 \%$ at urban and the lowest $16.45 \%$ at rural area, while the high percentage of seronegative $31.3 \%$ at rural and the lowest $25.8 \%$ at urban.

Table 5.Distribution of toxoplasmosis antibodies in rural and urban area of 310 aborted women.

\begin{tabular}{|c|c|c|c|c|}
\hline \multirow{2}{*}{ Residency } & \multicolumn{2}{|c|}{ ELISA Positive } & \multicolumn{2}{c|}{ ELISA Negative } \\
\cline { 2 - 5 } & No & $\%$ & $80^{\mathrm{a}}$ & 25.8 \\
\hline Urban $\mathrm{n}=162$ & $82^{\mathrm{a}}$ & 26.5 & $97^{\mathrm{a}}$ & 31.3 \\
\hline Rural $\mathrm{n}=148$ & $51^{\mathrm{b}}$ & 16.45 & $177^{\mathrm{a}}$ & 57 \\
\hline Total $\mathrm{n}=310$ & $133^{\mathrm{b}}$ & 43 & $\mathrm{X}^{2}=14 \quad \mathrm{DF}=3 \quad \mathrm{P} \leq 0.05$ \\
\hline Statistics & \multicolumn{3}{|c|}{} \\
\hline
\end{tabular}

Table 6. Show the high percentage of $T$. gondii antibodies of abortive women $(81.25 \%)$ at age (25-29) and the lowest $61.5 \%$ at age group 15-19 years.No infection with CMV, Rubella alone. In mixed infection (Toxoplasma and CMV), the high percentage $38.5 \%$ found at age $15-19$ years while the lowest $18.75 \%$ at age $25-29$ years.

Table 6:-The prevalence of T.gondii,Cytomegalovirus and Rubella in different age groups of abortive women.

\begin{tabular}{|c|c|c|c|c|c|}
\hline \multirow[t]{2}{*}{ Age (Year) } & \multicolumn{2}{|c|}{ Toxoplasma only } & \multicolumn{2}{|c|}{ Mixed Toxoplasma and CMV } & \multirow[t]{2}{*}{ Statistics } \\
\hline & No. & $\%$ & No. & $\%$ & \\
\hline $15-19 \quad n=13$ & $8^{\mathrm{a}}$ & 61.54 & $5^{\mathrm{a}}$ & 38.5 & \multirow{7}{*}{$\begin{aligned} X^{2}=68 \mathrm{DF} & =11 \quad \mathrm{P} \\
& \leq 0.05\end{aligned}$} \\
\hline $20-24 \quad n=39$ & $30^{\mathrm{a}}$ & 76.92 & $9^{\mathrm{b}}$ & 23.07 & \\
\hline $25-29 \quad n=32$ & $26^{\mathrm{a}}$ & 81.25 & $6^{\mathrm{b}}$ & 18.75 & \\
\hline $30-34 \quad n=27$ & $20^{\mathrm{a}}$ & 74.07 & $7^{b}$ & 26 & \\
\hline $35-39 \quad n=14$ & $10^{\mathrm{a}}$ & 71.43 & $4^{b}$ & 28.6 & \\
\hline$>40 \quad \mathrm{n}=8$ & $5^{a}$ & 62.5 & $3^{\mathrm{a}}$ & 37.5 & \\
\hline Total $n=133$ & $99^{\mathrm{a}}$ & 74.44 & $34^{\mathrm{b}}$ & 25.56 & \\
\hline Statistics & $\mathrm{X}^{2}=32 \quad \mathrm{DF}=$ & $\mathrm{P} \leq 0.05^{*}$ & $\mathrm{X}^{2}=$ & $\mathrm{P} \leq 0.53^{\mathrm{NS}}$ & \\
\hline
\end{tabular}

\section{Discussion:-}

Blood samples $310(66 \%)$ out of 470 aborted women were examined for Latex agglutination test, and out of 310 positive LAT $133(43 \%)$ samples gave positive with ELISA test. Therefore, the LAT test is less used tests for diagnosis the toxoplasmosis because it gives false positive, in comparison with ELISA test which have high efficiency for detected the acute and chronic infection. This result is consist with Razzak study [19 ] in Dohuk city who used the same test to examined 310 sample, 185 (59\%)samples gave positive result, but not agree with AlKaysi study [20] in Baghdad who recorded prevalence rates $28 \%$ by using the same test.

In 133 samples gave positive result (43\%) with ELISA test, the IgG positive was found in 113 case (36. 45\%), IgM positive 14 case $(4.52 \%)$, and (IgM\&IgG) in 6 case (1.97\%) from total of 305 examined samples give positive with (LAT). This result agree with Hadeel study in Babylon which showed $48 \%$ seroprevalent percentage in pregnant women [17], and Al-Adlaan study in Thi-Qar province who showed the serological test 42.45\% [16], but not agree with Kareem in Suliamania city who give seroprevalence ratio 32.6\% [18], and Al-Abody study in Thi-Qar who give 23\% in pregnant women [21], and Ylmazar study in Turkey who give 30.7\% in pregnant women [22].

The rate of infection is raised up in tropical and wet region because it is provide appropriate condition for growth the oocyst and their survival in soil [23,] and also raised up in countries that are consume the under cocked meat [24].

The high rate seropositive (12.58\%), of toxoplasmosis in this study was found in (20-24) age group, this agree with Al-Jubori study in Kirkuk city [25] which showed the high seropositive in the same age group (19-25), and also agree with study by Mohammaed in Waist city [26], which showed that the higher rate of aborted women in age group (20-30) years. The result in current study is not agree with study by Almayahi in Kute city which showed the highest percentage of infection in age group >25 years [27] and Jassem in Baghdad city which showed that high seropositive $60 \%$ was found in abortive women at age 35 year and the lowest percentage in age group (19-25) years[28]. 
The high prevalence of IgM, IgG in age group (20-24) is indicated that the women in this age period are very active in managing household matters and thus are more susceptible to risk factors and pass the infection [29], while the low percentage in age group $<40$ is due to less contact with causative agent of toxoplasmosis infection, and have low chance to be pregnant in this age.

This study shows the significant differences between antibodies according to the trimester time. The high seroprevalence ratio of IgG $100 \%$ found in third trimester higher than second and first trimester $(78.94 \%$, 85\%), while the IgM ratio was higher in first trimester $11.32 \%$ more than second $(10.53 \%)$. The IgG is the only anti-body that passed from mother to the fetus through the placenta and due to a defect in the process of transport of the antibody, which leads to accumulation in mother [30]. IgG is remain for long time and it is reffered to past infection, its increase may lead to new infection. The IgM antibodies appear during 1-2 week and transform to IgG.The above results is agree with AL-Ubaddy study [31], Al-Harthyi study in Sudia Arabia [32], and Akyar in Turkey [33] who recorded infection rate of $\operatorname{IgG} 24.6 \%$ and $\operatorname{IgM} 1.34 \%$. Fouladvand in Iran showed $\operatorname{IgM} 3.3 \%$ while $\operatorname{IgG} 23.4 \%$. [34].

The higher percentage of $\operatorname{IgG}(85 \%)$ more than $\operatorname{IgM}$ ratio $(11.3 \%)$ and both $(\operatorname{IgG} \& \operatorname{IgM}=10.53 \%)$, is not agree with other study in Najaf city [14] which showed the IgG positive (36\%) (IgM;IgG) (13.45\%) and IgM (5\%) respectively. But the present result show the lower ratio than other study by Mohammed in Kuffa city who showed the percentage of $\operatorname{IgG}$ and $\operatorname{IgM}(48 \%, 19.6 \%)$ respectively [35]. It is also not agree with study in Wassit which found the IgG positive (31.6\%) [36]. The results of the current study is not agree with AL-Kashaab study in Tikrit city who showed the $\operatorname{IgM}$ percentage ratio is more than $\operatorname{IgG}(58 \%),(32 \%)$ respectively [37]. Al-Garriry study [38] in Diyala show the higher percentage for $\operatorname{IgM}$ antibody $(23.5 \%)$ in compare with $\operatorname{IgG}(8.6 \%)$.

The study show the high rate of seropositive of $\mathrm{IgG}$ which is higher in women with recurrent abortive $100 \%$,than single aborted $78.57 \%$. The high ratio of $\operatorname{IgM}$ antibodies was found in single aborted women more than $\left(2^{\text {nd }} \& 3^{\text {rd }}\right)$ $(15.71 \%, 8.11 \%)$ respectively. This result is agree with Nazakat study in Kirkuk city of pregnant women which showed the same result [39]. The current study is not agreed with Aladlaan study in Thi-Qar who showed there is no significant relationship between the toxoplasmosis and the number of miscarriages [16].

The parasite is an opportunistic organism which remain in the body in a latent form and reactive the dividing in the depression of immunity. During pregnancy, the chronic infection may be transform to acute phase causing miscarriage.

Toxoplasmosis in this study showed significant difference according the residency, the seropositive (ELISA) of abortive women in urban $(26.5 \%)$ is higher than rural $(16.45 \%)$, it might be due to crowding people in the cities center and the environmental pollution compared with rural area which effects the immunity of women, In addition to bad habit for dietary and healthy such as eating fasting food exposes them to infection with toxoplasmosis [40]. The result of the present study is agree with study in AL-Najaf city [37] which showed the higher percent of toxoplasmosis in the urban area (67.6\%). and corresponding with study in Baghdad, by Khadime[41]. It is also agree with Al-Wattary study in Mosul city who showed there is significant difference between the infected women in urban more than rural[42].

The current study show the significant differences between the infection of $T$. gondii and mixed with CMV, in aborted women using ELISA test, IgG antibody was recorder with CMV infection but not with IgM antibodies. The prevalent of Toxoplasma, CMV, in all countries show (20-70\%), (40-100\%) respectively[43]. The IgG was recorded in rubella infection in most sample but it is not significant because most the pregnant women take the vaccine against Rubella or the women have past infection [44].

The Toxoplasma, CMV, and Rubella infections were among the most common causes for abortion in women but there is no link between them, mixed infection rarely showed together. In immunecompromised, provide opportunistic infection.

\section{Refrences:-}

1. Nelson, K. E; Williams,C. M.(2014). Infectious disease epidemiology theory ( $3^{\text {rd }}$ third edition). Baltimore. Maryland: Jones\&Bartle. 
2. Weiss, 1. K. (2007). Toxoplasma gondii the mode of apicomplexion perspective and methods. London. Academycrass

3. Monotoya, J. and Liesenfold, O. (2004). Toxoplasmosis. Lancet, 363:1955-1976.

4. Robert, G. F. and Darde, M. L. (2012). Epdemiology and diagnosis strategies for Toxoplasmosis. Cli. Microbiol. Rev., 25(2):264-296.

5. Perned, Z. J. and Federman, D. (2005). Toxoplasmosis in pregnancy, Amer. Med. J., 118: 212 -216.

6. Petersen, E. (2007). Toxoplasmosis semin fetal and neonatal medicine, Arhus. Univ. Danimark, (12) (214-233).

7. AL-Jebouri, M. ;AL-Janabi, M. and Ismail, H. (2013). The prevalence of Toxoplasmosis a mong female patients in AL-Hawija and Baijidistricts in Iraq. O. J. Epi., (3): 85-88.

8. Dabritz, H. A. and Conrad, P. A. (2011). Cats and Toxoplasma: implicatains for public health. J. Vet. Med., 57:34- 52.

9. AL-Nakib, W.; Ibrahim, M.E.; Hathout, H.; Moussa, M.A; Deverajan, L.V.;Thornburn, H. and Yusuf, A.M. (1983). Seroepidmiology of viral and Toxoplasma infection during pregnancy among Arab women of child breading age in Kuwait .Intr. Epidemoil., 12(2): 220.

10. Abdel -Hafez, S. K.; Shbeeb, I.; Ismail, N. S. and Abdel-Rahman, F. (1986). Serodiagnosis of Toxoplasma gondii in habitually abortion women and other adults from north Jordan. Folia. Parasitol., 33:7-13 .

11. AL-Meshari, A. A.; Chowdhury, M.N.; Chattopadhyay, S. K. and Desilva, S.K. (1989). Screening of Toxoplasmosis in pregnancy. Int. J. Gyanaecol. Obstet., 29(1):39-45.

12. Soliman, M; EL-Naggar, H.M. and EL-Chareb, M.E. (2001). Toxoplasma antibodies in normal and complicated pregnancy. J. Egypt. Soc. Parasitol., 31:37-46.

13. AL-Dageli, K. Y. (1998). Seroepidemiological study of Toxoplasmosis in women with recurrent abortion in Pporti city. M.Sc. Thesis. Coll. Veter. Univ. Baghdad. P (123).

14. Hasson, K. F. (2004). Sero-epidemiological study of toxoplasm-mosis among pregnant women with gynecological problem in Najaf city. M.Sc. (Thesis). Coll. Med. Unvi. Kufa., P95.

15. Yacoob, S.; Bakr, A.; Hameed. M.; Al-Thamery. M. and Fartocl. J.(2009). Seroepdimiology of selected Zoonotic infection in Basra region of Iraq Eastern. Mediteranean. Health. J. 12 (1): 82-85.

16. Al -Adlaan, A. J. (2007). Diagnostic and serological study of T. gondii for women whom had abortion by using PCR technique inThi-Qar province .M.Sc. Thesis, College of Education, Thi-Qar University.

17. Hadeel, S. H.; Raad, A. K.; Raheem, T. O. (2016).Seroepdemiological aspect for T. gondii infection in aborted women of Qadisiyah provinace, Int. J., (9). 11:252-259.

18. Kaream, L. A. (2007). Immunological and epidemiological study of T. gondii in abortion women in Suliamania city .MS.c. Thesis. Sci. Coll. Univ. Baghdad.

19. Razzak, A. H.; Wais, S. A and Saied, A. Y. (2005). Toxoplasmosis:The innocent suspect of pregnancy wastage in Duhok. Iraq.Est. Med. Heal., 11(4): 625 -632.

20. AL-Kaysi, A. M. (2001) Toxoplasmosis among random sample of Iraqi women and premature infants with certain immunological aspects M.Sc. Thesis. Univ. AL- Mustansiryah.

21. Al-Aboddy,R. K. (2014). Serological and molecular study of T. gondii and Rubella virus in abortion and pregnant women by using Real time PCR. MS.c. Thesis. Sci. Coll. Unive. Thi-Qar.

22. Yilmazer, M.; Altindis M.; Cevrioglu, S.; Fenkci V.; Aktepe O, and sirthan,E. (2004).Toxoplasma, Cytomegalovirus, Rubella, Hepatitis B,seropositivity rates in pregnant women who live in Afyon . Med. J. Kocatepe., 5: 49-53.

23. Pappas,G.; Roussos N. and Falagas M.E. (2009). Toxoplasmosis global status of Toxoplasma gondii seroprevalence and implications pregnancy and congenital toxoplasmosis. Int. J. Parasitol., 39 :1385-1394.

24. Scallan, E.; Hoekstra, R. M.; Angulo, F. J.; Tauxe, R. V.; Widdowson, M.A.; Roy, S. L.; Jones, J.L. and Griffin, P.M. (2011). Food borne illness acquired in the United States-major pathogens Emerg. Infect. Dis., 17:7-15.

25. Al-Jubori, A. R. (2005). Parasitological and immunological study of Toxoplasma gondii in Kirkuk provinace. M.Sc. Thesis. Coll. Since. Univ. Baghdad. P 82.

26. Mohammed, J. and Hadeel, A. (2011).performance of serological diagnosis of TORCH agents in aborted versus on-abortedwomen of waist provinace in Iraq. Tikrit. Med. J., 17(2):141-147.

27. Al- Mayahi, .R. G. (2011). Epidemiological study on Toxoplama gondii in aborted women in Kute city .M.Sc. Thesis. Coll. Scie. Baghdad Univ. Iraq. p65.

28. Jassem, F.S. (2010). Relatioship between Toxoplasmosis and testosterone hormone among Schizophrenic patients in Baghdad, M.Sc. Thesis. Coll. Council of health and Medical Technology. P.81.

29. Remington, J. S. ;Mcleod, R. ;Thulliez, P. and Desmont. (2001). Toxoplasmosis infection disease in fetus and new born Infant . W. B.SanderseCompany, Philadilphia. Remington. J. O. Klein. P 224-227. 
30. Abbas, Sh. K. (2005). Histological and Immunological study of the parasite in placenta of women infected with toxoplasmosis Ph.D. Thesis. Sinc. Coll. Mostansiria. Univ. P (180).

31. Al-Ubiady, N. A. (2011). Detection of portion Hsp70 in abortion women which they infection with Toxoplasma gondii. In Thi -Qar province. M.Sc. Thesis. Sci. Coll. Unvi. Thi- Qar.

32. Al-Harthi, S.A.;Jamjoom, M. B. and Ghazi, H. O. (2009). Seroprevalence of Toxoplasma gondii among pregnant women in Makkah, Saudi Arabia.; Umm Al-Qura. Univ. J. Science. Med. Eng., 18:217227.

33. Akyar, I. (2011). Seroprevalence and Coinfections of $T$.gondii inChild Bearing Age Women in Turkey. Iranian J. Public Health, 40 (1):63-67.

34. Fouladvand, M.; Barazesh, A.; Zandi, K.; Naeimi, B.andTajbakhsh, S. (2010).seroepdimiological study of toxoplasmosis in child bearing age women in Buhsher city, South weast Iran. Afarican. J. Biotech.9(36):58065812 .

35. Mohammed. K. G. (2011). Some Serological and molecular test used to identify Toxoplasmosis among women with abortion.Ph.D(Thesis). Coll. Med. Univ. Kuffa.

36. Tawffeeq, W.F.;Abed Russell K.H. and Saeed T.M.(2012). Seroprevalence and associate factors of Toxoplasma infection among sample of pregnant women. Wassit, Iraq. Med. Babylon.,9(4).

37. Al-Kashaab, F. M. (2009). Isolated and diagnosis the Toxoplasma gondii and it is immunological effective. Ph.D. Thesis. Sinc. Coll. Univ. Tikrit. P162.

38. Al-Garriry, A. J. (2007). Serological and epdimiological study of toxoplasmosis in Diayla provinac:,MS.c. Thesis. Scin. Coll. p94.

39. Nazakat,A. (2004). Seroprevalence study of Toxoplasma gondii among women in Kirkuk city. M.Sc. Thesis. Coll. Med. Univ. Tikrit.

40. Suarez,O. and Estevenz, J.(2009). Seroepidemiologyof toxoplasmosis infection in women of childbearing age from a marginal community of Maracaibo, Venezuela. Inst. Med.Trop.Sao.Paulo., 51(1):13-17.

41. Khadim, M.A. (2006). Study of some immunelogical parameters of women Sero infected with toxoplasmosis. M.Sc. Thesis. Coll. Sci. Uni. Baghdad.

42. Wattary, A.T.A. (2005). Prevalence of anti-toxoplasmosis antibodies among women in Mosul city .M.Sc. Thesis, Univ. Mosul. Coll. Medicine.

43. Novotná, M.; Hanusova, J.; Klose, J.; Preiss, M.;Havlicek, J. Roubalová,K. and Flegr, J.(2005). Probable neuro immunological link betweenToxoplasma and Cytomegalovirus infections and personality changes in the human host. BMC Infectious Diseases.Bio Med Central Ltd., (5):54.

44. Chopra, S.; Arora, U. and Aggarwal, A.(2004). Prevalence of IgM Antibodies to Toxoplasma, Rubella and Cytomegalo virus Infections during Pregnancy.,6(4):190-192. 